\title{
Co-Movement and Index Changes - Evidence from The Emerging Indian Stock Market
}

\author{
Srikanth Parthasarathy \\ Assistant Professor \\ Bharathidasan Institute of Management \\ Tiruchirappalli 620014, India \\ Tel: 91-909-413-5843Ｅ-mail: psrikanth2011@gmail.com
}

Received: August 17, 2011 Accepted: December 8, 2011 Published: December 1, 2011

doi:10.5296/ajfa.v3i1.835 URL: http://dx.doi.org/10.5296/ajfa.v3i1.835

\begin{abstract}
This study investigates the return co-movement around the benchmark Nifty index changes for the period 1999-2010 in the Indian stock market. We find evidence of significant increase in co-movement between the added stocks and the Nifty index subsequent to additions to the benchmark Nifty index. On the contrary stocks deleted from the Nifty index do not evidence decreased co-movement between the deleted stocks and the Nifty index. We have employed various methodologies used by Vijh(1994), Barberis et al(2002) and Greenwood and Sosner (2002) and the results suggest that the information related views explain the Nifty index changes in the emerging Indian stock market.
\end{abstract}

Keywords: Indian Equity market, Index changes, Co-movement, Information

JEL classification: G11, G12, G14. 


\section{Introduction}

The empirical investigation of stock index changes around the world has focused on two aspects: Firstly, the price effect which was studied for over the past three decades had evidenced permanent increase in stock prices following addition to stock index. Shiefler (1986), Lynch and Mendenhall (1997), Wurgler and Zhuravskaya (2002) have found evidence for permanent price effects following addition to S\&P 500 index. Greenwood (2003) evidenced similar price effects in the Tokyo stock market.

Secondly, the return co-movement ${ }^{1}$ as measured by stock beta, between the added (deleted) stocks and the market index following addition (deletion) to (from) the market index. Pioneering work on co-movement around index changes was done by Vijh (1994) and later by Barberis et al (2002). Vijh (1994) discriminated between the price pressure hypothesis and non-synchronous trading hypothesis as the explanations for co-movement subsequent to index changes. According to Mitchel et al(2004), the price pressure hypothesis asserts that prices will temporarily move away from their intrinsic values with uninformed shifts in order to compensate the liquidity providers. According to Harris and Gurel (1986), the price pressure hypothesis assumes that investors who accommodate demand shifts should be compensated for the transaction cost and the portfolio risk they bear when they agree to buy or sell stocks which otherwise they would not trade. The suppliers of liquidity are compensated by immediate price drops (increases) with large sales (purchases). On the other hand, according to Scholes and Williams (1977) trading activity around index addition might enable investors to trade the index portfolio more efficiently (non-synchronous properties). This enables bench mark index stocks to incorporate market wide information immediately compared to non-benchmark stocks which impound information with a lag. The study shows that non-synchronous trading also biases the estimated stock betas.

Barberis et al (2002) analyzing the S\&P 500 index additions discriminated between the three co-movement views, namely category view, habitat view and finally the information diffusion or fundamental view. In the category view, the investor's, like index traders, group assets or stocks into categories and when they move from one category to another, co-movement is generated between assets in the same category. Similar explanation is the habitat view in which a group of investors for various reasons choose to trade only in a subset of assets $^{2}$ and move in and move out of them together due to transaction costs, trading restrictions or lack of information. The above views posit that the increased co-movement is due to trading actions of the index funds, co-movement is generated. Finally the information view relates co-movement to rapid incorporation of information in benchmark index stocks compared to other stocks because of market frictions. Consequently the stocks tend to co-move with the index. Overall the debate is whether the increased co-movement subsequent to index addition is due to behavioral / index trading or traditional / fundamental based reasons.

\footnotetext{
${ }^{1}$ Co-movement is defined as a pattern of positive correlation (Barberis et al, 2002). Dirk Baur (2003) explains co-movement as a phenomenon in which an asset (price) is 'moving with' another asset (price) and defines co-movement as the movement of assets that is shared by all assets at time' $t$ '

${ }^{2}$ For example, some investors may trade only in the Indian stocks which are included in the MSCI index etc.
} 
Though this is well researched topic in the developed markets, there are few studies in the emerging markets like India on index changes in general and co-movement in particular. The importance of these studies in the Indian stock market can be appreciated based on the fact that the Indian equity market stood $13^{\text {th }}$ in the world and $4^{\text {th }}$ in Asia in terms of both traded value ( $\$ 1050$ bn during the year) and market capitalisation ( $\$ 645$ bn at the year end $)^{3}$ in 2008. The increasing international portfolio investment and participation provides a perfect platform for gathering information about the market structure, efficiency and evidence of the integration mechanism with the developed markets. The Indian stock market differs from the developed markets in the following ways; the Indian stock market ${ }^{4}$ is characterized by less informational efficiency, higher costs, smaller investor base and lower liquidity compared with the stock markets of developed countries. Finally, unlike the developed markets, there may be drastic difference in the quality of assets between benchmark index and other index stocks. This is truer for the foreign investors' as local factors affect pricing significantly. Hence, it will be interesting to analyse whether the results evidenced in the developed markets apply to emerging markets like India. This is very important as countries like India have looked upon the developed countries for their financial sector policies. These studies will help the decision makers to appreciate the differences or similarities between the emerging and developed countries and to take informed policy decisions. The co-movement following index changes has implications for portfolio managers as they might alter the return correlation due to conventional factors like industry etc.

The purpose of this study is to analyse the co-movement subsequent to Nifty index changes by comparing the 'beta' of the added/deleted stocks before and after the addition and deletion to benchmark Nifty index. The increased (decreased) co-movement may be either due to trading strategies of institutional investors post inclusion or due to fundamental reasons. This study enters the debate by positing that the Nifty index additions might be accompanied by increased comovement and fundamental explanations like information diffusion view (Barberis et al,2002) or the non-synchronous trading hypothesis( Vijh, 1994) might explain the increased co-movement. This study contributes to ever growing index addition literature by studying the co-movement between the added (deleted) stocks and the Nifty market index following addition (deletion) to (from) the Nifty market index in the Indian stock market.

The second section details the existing literature. The third section details the Nifty index selection, methodology and data. The fourth section reports and analyses the findings and the fifth section concludes.

\section{Review of Literature}

\subsection{Theories of Co-movement}

The explanations for increased co-movement post index additions have revolved around two groups of explanations namely; while Vijh (1994) discriminated between the price pressure

\footnotetext{
${ }^{3}$ Please see http://nse-india.com/archives/us/ismr/us ismr2009.htm for more details.

${ }^{4}$ Chakrabarti(2002) and Hacibedel(2008) have discussed the differences between developed and emerging markets extensively.
} 
hypothesis and non-synchronous trading hypothesis as the explanations for co-movement subsequent to index changes, Barberis et al (2002) discriminated between the three co-movement views, namely category view, habitat view and finally the information diffusion or fundamental view.

According to the price pressure hypothesis, large trading volume in premier index stocks like the Nifty stocks would cause price pressures because of short term demand-supply considerations. This may be due to the fact that someday 'buy' orders may dominate and on other days 'sell' orders might dominate. This also may be caused by large trades based on investment strategies following index changes etc. According to Mitchel et al (2004), the price pressure hypothesis contends that prices will temporarily move away from their intrinsic values with uninformed shifts in order to compensate the liquidity providers. According to Harris and Gurel (1986), the price pressure hypothesis assumes that investors who accommodate demand shifts should be compensated for the transaction cost and the portfolio risk they bear when they agree to buy or sell stocks which otherwise they would not trade. The suppliers of liquidity are compensated by immediate price drops (increases) with large sales (purchases). The index funds and other institutional investors have to rebalance their portfolios immediately following the effective date of index changes due to tracking error. Vijh (1991) opines that price pressure might overstate Nifty stock betas and understate non-Nifty stock betas. Parthasarathy (2010) evidenced that the effect of price pressure is very limited at best based on the price and volume effects following Nifty index additions in the Indian stock market.

Scholes and Williams (1977) contended that the trading activity around index addition might enable investors to trade the index portfolio more efficiently (non-synchronous properties). This enables bench mark index stocks like the Nifty index stocks to incorporate market wide information immediately compared to non-benchmark stocks which impound information with a lag. The study shows that non-synchronous trading also biases the estimated stock betas. If the changes in co-movement are driven by the non-synchronous trading, beta increase should be evidenced only in the stocks experiencing increased volume and not for the stocks that did not experience volume increase. However, according to the price pressure all the added stocks would experience beta increase irrespective of the post inclusion volume.

Barberis et al (2002) discriminated between the three co-movement views, namely category view, habitat view and finally the information diffusion or fundamental view. In the category view, the investor's, like index traders, group assets or stocks into categories and when they move from one category to another, co-movement is generated between assets in the same category. The idea is that investors choose to asset allocation rather than security analysis and hence choose the category like the index funds rather than the individual stocks. The implication is that the correlation among stocks is due to investor actions and not due to fundamental reasons. Similar explanation is the habitat view in which a group of investors for various reasons choose to trade only in a subset of assets and move in and move out of them together due to transaction costs, trading restrictions or lack of information. The above views posit that the increased co-movement is due to trading actions of the index funds, co-movement is generated. The habitat view is based on the segmented market approach. 
There are two implications of the category and habitat views; firstly, increased co-movement in the latest period along with the growth of index funds and secondly, symmetric response to index additions and deletions with regard to co-movement. Finally the information view relates co-movement to rapid incorporation of information in benchmark index stocks compared to other stocks because of market frictions. Consequently the stocks tend to co-move with the index.

\subsection{Empirical Literature}

The existing literature on co-movement between the added stocks and the market index following addition to the market index predominantly deals with developed markets. However there is some literature regarding co-movement and stock synchronicity in the emerging economies. The literature on the developed economies is discussed first.

Vijh (1994) analysed 329 stocks added to the S\&P 500 index during the 1975-1989 period. He evidenced increased stock beta subsequent to index additions. He evidenced an increase of 0.211 and 0.130 in daily and weekly betas respectively. He found evidence that the increase in co-movement was predominantly due to index trading strategies rather than the reduction of non-synchronicity. Though both the price pressure hypothesis and non-synchronous trading hypothesis support increased beta for S\&P 500 stocks and reduced beta for non- S\&P 500 stocks, Vijh(1994) asserts that the cross sectional implication would be different. The non-synchronous trading hypothesis expects that increase or decrease of individual stock beta depends on the before and after trading volume. It predicts that for the stocks whose trading volume, subsequent to index addition, decreases, the stock beta will decrease and vice versa. The price pressure hypothesis predicts that as the addition of a stock to the premier index always increase the covariance with the market returns and hence the stock beta of individual stocks will always increase irrespective of trading volume.

The second important study regarding stock co-movement subsequent to index inclusion was by Barberis et al (2002). They studied S\&P 500 index inclusions and exclusions using weekly data for the period 1976-2000. They evidenced an increase of 0.11 and 0.03 in stock beta and co-efficient of determination ' $\mathrm{r}$ ' respectively. They introduced the non-S\&P stock returns ${ }^{5}$ into the regression independently. The bivariate regression evidenced even starker confirmation of increased co-movement. The beta increase was 0.21 while the beta decrease for the non-S\&P stocks was -0.12. Barberis et al provided support in favor of behavioral views like category and habitat views rather than fundamental view for S\&P 500 stock inclusion by evidencing that the results were stronger in the later period and were robust to both size and industry characteristics.

Greenwood and Sosner (2002) studied the one time inclusion of 30 stocks to the Japanese Nikkei index in the year 2000. They evidenced a significant increase of 0.6 in daily stock betas subsequent to addition and a significant decrease of 0.71 subsequent to deletions. This study also supported the behavioral / trading related views for the increased co-movement. Coakley and Kougalis (2004) studied post inclusion co-movement in the FTSE100 index on

\footnotetext{
5 Total market return minus S\&P 500 returns.
} 
the lines of Barberis et al. The univariate regressions using the FTSE100 index returns evidenced post inclusion daily beta change of 0.34 and -0.35 for inclusions and exclusions respectively. The weekly beta increase was 0.16 post inclusion. The bivariate results using the FTSE100 index and non- FTSE100 index returns evidenced post inclusion daily beta increase of 0.51 . The weekly results evidence beta increase of 0.603 for FTSE stocks and -0.872 for non-FTSE stocks.

J.Coakley et al.(2008) studied MSCI Canada standard country index rebalancing wherein 17 stocks were added and 13 stocks were deleted in the year 2000. They evidenced an average beta increase by a factor of 1.6 for the added stocks and by a factor of -0.05 for the deleted stocks and supported the trading related views.

However the evidence in favor of trade related co-movement in the developed markets is not unanimous. Kasch and Sarkar(2009) examining S\&P 500 inclusions for the period 1989-2004 showed significant co-movement and concluded that changes in co-movement subsequent to S\&P 500 additions reflect changes in the expectation about the fundamental value of added firms. Claessens and Yafeh(2009) studied co-movement subsequent to index additions for the period 2001-2007 in 39 developed and emerging markets around the world. They concluded that in less developed markets the increase in co-movement is due to information related problems.

Finally, Chen et al (2004) analysed the price and volume effects of the S\&P 500 index changes. They evidenced asymmetric results for additions and deletions regarding permanent price increase. He attributes this to the 'investor awareness view' which contends that many investors can become aware of the added stocks leading to permanent price increase. But the investors do not become unaware of the deleted stocks and hence deleted stocks may not evidence permanent price decrease post deletion. Parthasarathy (2010) examined the price and volume effects of the Nifty index additions in the Indian stock market in the 1999-2010 period and concluded that the information related explanations explain the evidenced permanent increase in price.

\section{Data and Background Information}

\subsection{The Nifty index}

The S\&P CNX Nifty (Nifty hereafter) is the headline index on the National stock exchange (NSE) maintained by the India index services and products Ltd. (IISL) from 1998. It represents a portfolio of 50 large and most liquid stocks of the NSE and captures $65 \%$ of the total market capitalization. The NSE is the premier exchange of India in terms of market capitalisation and value traded. The main criteria of selection of stocks for the Nifty index are market capitalization, float, liquidity and industry representation. The index is normally reviewed every six months and six weeks' notice is normally given to the market after announcement before change is effected. Index removal is normally effected either due to corporate actions like restructuring etc. or when market capitalisation of an index stock falls below $50 \%$ of the market capitalisation of the top most stock of the replacement pool (Top Nifty Junior stock). Normally Nifty index replacements are top most stock of the Nifty Junior 
index. Nifty and Nifty Junior index represents two disjoint sets together representing the top 100 stocks in the Indian stock market.

\subsection{Sample selection}

The sample period for this study is 1999 - 2010, coincides the starting year of index funds in India. This choice of the period will help us to discriminate between the various theories as the index funds play an important part in the price pressure hypothesis. Also details regarding both announcement date (here after AD) and Effective date of inclusion/exclusion (here after ED) are available only from 1998 onwards. The daily data from www.nse-india.com is used to calculate daily return and daily volume of the added stocks and Nifty index.

The sample consists of 41 inclusions and 30 deletions. The following stocks are not considered: stocks arising out of corporate restructuring, stocks which do not have trading history for at least 100 trading days prior to the announcement date in the case of additions and at least 70 trading days post deletion in the case of deletions.

The total number of Nifty index changes for the $1999-2010$ period is 54 . The total number of stocks available for research after the elimination is 41 in the case of additions and 30 in the case of deletions. The sample is separated into two periods namely, 1999 - 2006 and 2007 2010 as the latter period is marked by increased fund activity and participation and is more representative for the current market activity.

\subsection{Return and Volume}

Daily return $R_{t}$ is calculated as

$$
\mathbf{R}_{\mathbf{t}}=\operatorname{Ln}\left(\mathbf{P}_{\mathbf{t}}\right)-\operatorname{Ln}\left(\mathbf{P}_{t-1}\right)
$$

Where $\mathrm{P}_{\mathrm{t}}$ is the stock / nifty index / nifty junior closing price at time $\mathrm{t}$ and $\mathrm{P}_{\mathrm{t}-1}$ is the stock / nifty index / nifty junior closing price at time $\mathrm{t}-1$.

The volume effect is studied in the spirit of Harris and Gurel(1986) where

$$
\text { Volume Ratio VR }=\left(V_{\text {it }} / V_{m t}\right) \div\left(V_{i} / V_{m}\right)
$$

Where $V_{i t}$ and $V_{m t}$ are the trading volumes at time ' $t$ ' of security $i$ and the total NSE respectively, and $\mathrm{V}_{\mathrm{i}}$ and $\mathrm{V}_{\mathrm{m}}$ are the average trading volumes of the security $i$ and total NSE for the period $\mathrm{AD}-70$ (70 days before announcement) through AD-10. The calculated daily VR is used to calculate the 'VR' for the period ED+10 to ED+70. The volume ratio ${ }^{6}$ should have a value of 'one' under null hypothesis. If for a stock $\mathrm{VR}>1$, then post inclusion volume is more than the pre inclusion volume and vice versa.

\subsection{Descriptive statistics}

Table 1 describes the growth of market capitalization, mutual funds and average trading volume from the year 1999 to 2009 . The table 1 also details the number of yearly additions to the Nifty index and the beta change for the added stocks after inclusion into the index. There

\footnotetext{
${ }^{6}$ Volume in this study is the number of shares traded. The stock volume is standarised using the total NSE market volume. The calculation of volume ratio takes into account the capitalization changes
} 
is a steep increase in all the variables like market capitalization, mutual funds assets and average daily trading volume except for the years 2001 and 2008 suggesting increased participation from various market players..

Table 1. Yearwise ED abnormal return and Beta change is given for the period 1999-2010 in order to verify whether the beta change is stronger in the latest data.

\begin{tabular}{|r|c|c|c|r|r|}
\hline Year & $\begin{array}{c}\text { Number of } \\
\text { additions }\end{array}$ & $\begin{array}{c}\text { BETA } \\
\text { Change }\end{array}$ & $\begin{array}{c}\text { Average assets } \\
\text { under Mutual } \\
\text { funds in Rs. } \\
\text { millions }\end{array}$ & $\begin{array}{c}\text { Market } \\
\text { capitalisation in } \\
\text { Rs. millions }\end{array}$ & $\begin{array}{c}\text { Average daily } \\
\text { trading volume } \\
\text { in Rs. millions }\end{array}$ \\
\hline 1999 & 5 & -0.219 & 970280 & 10204260 & 33030 \\
\hline 2000 & 4 & 0.423 & 993260 & 6578470 & 53370 \\
\hline 2001 & 0 & 0 & 1018220 & 6368610 & 20780 \\
\hline 2002 & 6 & 0.167 & 1226600 & 5371330 & 24620 \\
\hline 2003 & 3 & 0.088 & 1400930 & 11209760 & 43290 \\
\hline 2004 & 4 & 0.049 & 1505370 & 15855850 & 45060 \\
\hline 2005 & 2 & 0.515 & 1992480 & 28132010 & 62530 \\
\hline 2006 & 2 & 0.182 & 3235970 & 33673500 & 41480 \\
\hline 2007 & 6 & 0.37 & 5499360 & 48581220 & 113250 \\
\hline 2008 & 3 & 0.057 & 4211170 & 28961940 & 169590 \\
\hline 2009 & 6 & -0.031 & 7944860 & 60091730 & \\
\hline$T$
\end{tabular}

The data is given for the period 1999-2010. The number of additions to Nifty index each year. the daily pre-event regression is run for the period AD-130 to AD-11 (120 trading days). The daily post event regression is run for $\mathrm{ED}+10$ to $\mathrm{ED}+130$. When data for 130 days are not available, the estimation period is shortened to 90 days in case of addition and 60 days in case of deletion. The point of interest is the difference ' $\beta_{\mathrm{c}}$ ' which is calculated for each added/deleted stock by subtracting the pre event beta from the post event beta. The mean yearly beta is the average beta of all the added stocks in a year. The average assets under mutual funds represent assets as on $31^{\text {st }}$ December of each year. The average assets under mutual funds(year end) is regressed with yearly mean beta change in order to verify whether the beta change is stronger in the latest data. The market capitalisation and average daily trading volume are given as on march 31 st of the respective financial year ${ }^{7}$.

\section{Analysis and Findings}

\subsection{Univariate Regressions}

The following regression was run for each of the 41 added and 30 deleted stocks using approximately six months data, both pre-announcement and post-inclusion.

$$
\mathrm{R}_{\mathrm{it}}=\alpha+\beta * \mathrm{R}_{\text {nifty,t }}+\varepsilon_{\mathrm{it}}
$$

\footnotetext{
${ }^{7}$ Based on NSE fact book 2011.
} 
where, $R_{i t}$ is stock return, $R_{\text {nifty,t }}$ is the Nifty index return on day ' $t$ ', $\beta$ is the regression slope beta co-efficient and $\varepsilon_{\text {it }}$ is a random variable with expected value of zero assumed to be uncorrelated $^{8}$ with $\mathrm{R}_{\text {nifty,t. }}$. For the additions, the daily pre-event regression is run for the period AD-130 to AD-11 (120 trading days). The daily post event regression is run for $\mathrm{ED}+10$ to $\mathrm{ED}+130$. When data for 130 days are not available, the estimation period is shortened $^{9}$ to 60 days in case of addition and 60 days in case of deletion. The point of interest

is the difference ' $\beta_{\mathrm{c}}$ ' which is calculated for each added/deleted stock by subtracting the pre event beta from the post event beta. The hypothesis that $\beta_{\mathrm{c}}$ is significantly greater than zero is first tested cross sectionally using one-tailed t-test. The post inclusion/exclusion regression starts only from the $11^{\text {th }}$ day after inclusion as the first few days after inclusion will be characterized by sudden increase in volume and volatility due to action of index funds. Consequently, in order to maintain symmetry, the pre-event regression ends 10 days before the announcement date.

The results of the univariate regression of added stocks are reported in Table 2, Panel A. According to Barberis et al(2002) preposition I, for category based co-movement added (deleted) stock should experience a beta increase (decrease). The Nifty index additions experience a statistically significant positive change in the betas(slope co-efficient) post inclusion. The average beta change for the complete period is 0.140 . The beta change is also statistically significant in both the sub periods. The average beta change in the first and second sub period is 0.133 and 0.153 respectively. The results of the univariate regression of deleted stocks are reported in Table 2, Panel B. Nifty deletions experience a beta increase of 0.045 , though not statistically significant, instead of an expected significant beta decrease. Also both the sub periods do not evidence significant beta decrease. The result for deletions is also different from the evidence in the developed markets. The lack of symmetric response to additions and deletions does not support the Barberis et al (2002) 'category view'. The results seem to support the Chen et al (2004) explanation of 'investor awareness' as an explanation index changes in the Indian stock market.

\footnotetext{
8 This assumption is valid in the Nifty index changes because unlike the western equity markets, the Nifty index changes do not normally feature multiple additions. There are 29 unique additions(29 different inclusion days) for the total of 41 additions. See Coakley and Kougalis (2004) for more information on this issue.

9 The estimation period is shortened for only two added stocks and one deleted stock.
} 
Table 2. Changes in co-movement measured by daily beta before and after addition of stocks to Nifty index

\begin{tabular}{|c|c|c|c|c|c|c|}
\hline \multicolumn{2}{|c|}{ Panel - A } & \multicolumn{5}{|c|}{ Results of Univariate regression -Additions } \\
\hline Period & $\begin{array}{c}\text { No. of } \\
\text { additions }\end{array}$ & $\begin{array}{l}\text { Average } \\
\text { beta before } \\
\text { inclusion }\end{array}$ & $\begin{array}{l}\text { Average } \\
\text { beta after } \\
\text { inclusion }\end{array}$ & & $\begin{array}{c}\text { Increase in } \\
\text { beta }\end{array}$ & $\begin{array}{c}\% \text { of stocks } \\
\text { with beta } \\
\text { increase }\end{array}$ \\
\hline \multirow[t]{2}{*}{ 1999-2010 } & 41 & 1.013 & 1.153 & $\beta_{\mathrm{c}}$ & 0.140 & $57 \%$ \\
\hline & & & & t-stat & $2.131 * *$ & \\
\hline \multirow[t]{2}{*}{ 1999-2006 } & 26 & 0.950 & 1.083 & $\beta_{\mathrm{c}}$ & 0.133 & $58 \%$ \\
\hline & & & & t-stat & $1.504^{*}$ & \\
\hline \multirow[t]{2}{*}{$2007-2010$} & 15 & 1.125 & 1.278 & $\beta_{\mathrm{c}}$ & 0.153 & $54 \%$ \\
\hline & & & & t-stat & $1.585 *$ & \\
\hline \multicolumn{7}{|c|}{ Panel - B } \\
\hline Period & $\begin{array}{c}\text { No. of } \\
\text { deletions }\end{array}$ & $\begin{array}{c}\text { Average } \\
\text { beta before } \\
\text { deletion } \\
\end{array}$ & $\begin{array}{l}\text { Average } \\
\text { beta after } \\
\text { deletion }\end{array}$ & & $\begin{array}{c}\text { Increase in } \\
\text { beta }\end{array}$ & $\begin{array}{c}\% \text { of stocks } \\
\text { with beta } \\
\text { increase }\end{array}$ \\
\hline \multirow[t]{2}{*}{ 1999-2010 } & 30 & 0.793 & 0.838 & $\beta_{\mathrm{c}}$ & 0.045 & $56 \%$ \\
\hline & & & & t-stat & 0.783 & \\
\hline \multirow[t]{2}{*}{$1999-2006$} & 19 & 0.821 & 0.890 & $\beta_{\mathrm{c}}$ & $\mathbf{0 . 0 7}$ & $63 \%$ \\
\hline & & & & t-stat & 0.947 & \\
\hline \multirow[t]{2}{*}{$2007-2010$} & 11 & 0.745 & 0.747 & $\beta_{\mathrm{c}}$ & 0.002 & $37 \%$ \\
\hline & & & & t-stat & 0.026 & \\
\hline \multicolumn{7}{|c|}{$\begin{array}{l}\text { The sample of addition to Nifty index for the period } 1999-2010 \text { consists of } 41 \text { added stocks } \\
\text { and } 30 \text { deleted stocks which are not involved in mergers/demerger and related events anc } \\
\text { have sufficient daily data. For each added/deleted stock the betas are estimated for both the } \\
\text { pre-change and post-change period. Pre-change betas and post-change betas are calculatec } \\
\text { using daily data for the period AD- } 130 \text { to AD-10 and period ED+10 to ED+130 } \\
\text { respectively(120 trading days) using daily log returns in univariate market model. The } \\
\text { statistical significance is tested cross sectionally using one-tailed t-test. ***,**,* denotes } \\
\text { statistical significance at } 1 \%, 5 \% \text { and } 10 \% \text { level respectively. }\end{array}$} \\
\hline
\end{tabular}

However, if the stocks ${ }^{10}$ with substantial pre addition/deletion and post addition/deletion time series falling in the recession period Jan-2008 to Mar 2009 is removed, the second sub-period mean beta change for addition increases to 0.233 from 0.153 but for the deletions decreases from -0.002 to a still not significant -0.027 . Similarly the percentage of stocks with positive beta change increases to $70 \%$ from $54 \%$ in the case of additions. Further, the recent period results after removing the recession period data are still not in line with that of the developed markets with significant beta increase for additions and small beta decrease (statistically not significant) for deletions.

\footnotetext{
${ }^{10}$ Five stocks in addition and four stocks in deletion.
} 
In order to verify that few outliers do not cause the results, the percentage of stocks with beta increase is calculated for both the additions and deletions. The percentage of stocks with positive beta change is over $50 \%$ for the complete period for not only the added stocks but also the deleted stocks. This suggests that the results are not due to a few outliers. The asymmetric results for the addition and deletion do not appear to support category based reasoning in Barberis et al preposition I for the co-movement subsequent to Nifty index changes.

We have also used a matched sample methodology (results not showed for brevity) using firms that have not been added from the Nifty Junior index. This is important since stocks over this period could be showing increased co-movement with the index in general and the observed increased co-movement might have nothing to do with addition to the index. We have chosen ten random stocks representing all the major industries from the Nifty Junior index and have calculated ' $\beta_{\mathrm{c}}$ ' for these Nifty Junior stocks similar to the added stocks using the same AD and ED and is calculated for each by subtracting the pre event beta from the post event beta for 11 different event dates. The matched sample results evidence of ' $\beta_{\mathrm{c}}$ ' equal to -0.038 as against 0.140 for the added stocks. Further, we ran a regression between the matched sample ' $\beta_{\mathrm{c}}$ ' and with that of the actual added stocks using the 11 different event dates. A significantly positive slope coefficient would suggest that the co-movement is not due to addition and may be due to increased co-movement with the index in general and the observed increased co-movement might have nothing to do with addition to the index. The regression slope co-efficient was negative (though not statistically significant) implying no correlation between the beta change of the added stocks and the matched sample stocks. This confirms that the increased co-movement is due to index addition only.

In order to test for the Barberis et al (2002) assertion that if the index trading strategies are the main reason for the significant co-movement, the results should be stronger in the later sub-period along with the growth of index funds. The difference between the beta changes in both the sub periods in Panel A is compared using both parametric (two sample t-test) and non-parametric tests (Mann Whitney test). The tests unanimously suggest that the difference in beta changes between the two sub-periods is not significant at any level of significance ${ }^{11}$ suggesting that the beta change is not significantly stronger in the later period. This result does not support the index trading strategies assertion. Further if the beta effect $\left(\beta_{\mathrm{c})}\right.$ gets stronger along with the growth of index funds ${ }^{12}$, a significantly positive slope co-efficient should result when yearly beta change (Table 1) is regressed with the yearly average value under mutual funds. However the regression ${ }^{13}$ slope co-efficient is found to be almost zero and is not statistically significant at any level of significance. The results of this study differ from those of Barberis et al(2002) and Coakley and Kougalis (2004) in not supporting the index trading based co-movement as the reason for co-movement subsequent to index additions. The above results along with the univariate results for deletions do not support the

\footnotetext{
11 The results of the two sample test (1999-2006 and 2007-2010): Parametric test: t-value is $\quad-0.215$, p-value : 0.831 . Non parametric test: value is -0.293 , p-value $: 0.769$.

12 As the data for index fund growth in the Indian market is not available, the mutual fund data is used as a proxy in this study. The average assets under mutual fund as on 31, December. The source is www.amfiindia.com.

${ }_{13}$ The D-W stat is within limits for all the regressions.
} 
no-information assertion for Nifty index additions and differs from those of the developed countries.

\subsection{Bivariate Regressions}

Barberis et al(2002) introduced the bivariate regression in their preposition II by introducing non-S\&P 500 returns independently in the regression and stated that controlling for non- S\&P 500 stocks, stocks added to (deleted from) the S\&P 500 index will experience a beta increase (decrease). In the Nifty index additions, stocks are added from among the top market capitalization stocks of 'Nifty Junior' index but the stocks deleted from the Nifty index are not included back in the Nifty Junior index. The following bivariate regression is run for all the added stocks,

$$
\mathrm{R}_{\mathrm{it}}=\alpha+\beta_{\mathrm{i}, \text { nifty }} * \mathrm{R}_{\mathrm{nifty}, \mathrm{t}}+\beta_{\mathrm{i}, \text { niftyjunior }} * \mathrm{R}_{\text {niftyjunior } \mathrm{t}}+\varepsilon_{\mathrm{it}}
$$

where $R_{\text {niftyjunior,t }}$ is the Nifty Junior index return on day ' $t$ '. Barberis et al(2002), Coakley and Kougalis (2004) have calculated and used the non-S\&P 500 and non-FTSE return respectively in the bivariate regression using the total market return and total market capitalization data in their respective markets. Due to paucity of such readily available data in the Indian stock market and due to the fact that stocks added to nifty as a rule comes from Nifty Junior index, $R_{\text {niftyjunior, }}$ is used in this study. Also as the stocks deleted from the Nifty index are not included back in the Nifty Junior index, similar bivariate regression would not make sense for stocks deleted ${ }^{14}$ from Nifty index. According to Barberis et al (2004), In the category view, the basic prediction is that, when a stock enters a bench mark index like Nifty, it becomes more sensitive to that bench mark index sentiment shock. The independent variable in the univariate regression in eq(3) is not a clean measure of this sentiment shock as a substantial part of its variation might come from news about cash flows. The $\beta_{\text {i,niftyjunior }}$ variable in eq(4) can be thought of as a control for such news, making the $\beta_{i, n i f t y}$ in eq(4) a cleaner measure of sensitivity of such sentiment shock. Alternatively, under the information diffusion view, eq(4) is a cleaner test than eq(3) of whether, after inclusion, stock i becomes more sensitive to that component of market-wide news that is incorporated more quickly into Nifty index than into NiftyJunior index.

The results of bivariate regession are displayed in Table 3 . The average change in $\beta_{\text {nifty }}$ and average change in $\beta_{\text {niftyjunior }}$ for the complete period is 0.532 and -0.442 respectively and statistically significant. The results for both the sub periods are statistically very significant. The Though the change in $\beta_{\text {nifty }}$ and $\beta_{\text {niftyjunior }}$ is as per the predictions of preposition II of Barberis et al(2002) and similar to the results evidenced in the developed countries, the beta change for the later sub-period is not stronger than for the earlier sub-period which suggests again that the index trading strategies may not be the primary reason for the increased co-movement subsequent to additions and differs from the results in developed markets. Moreover, in the developed markets the magnitude of decrease in non S\&P / Non FTSE beta was equal or more than the magnitude of increase in S\&P / FTSE beta. However, in the Indian stock market the magnitude of decrease in Niftyjunior beta was markedly lower than

\footnotetext{
14 For the stocks deleted from nifty index, bivariate regression was run using Nifty Junior index. The average change in $\beta_{\text {nifty }}$ and average change in $\beta_{\text {niftyjunior }}$ for the complete period is not statistically significant.
} 
the magnitude of increase in Nifty beta in the complete period and even lower in the later period for Nifty additions. It is seen from table 3 that the $\beta_{\text {nifty }}$ increase for the later period

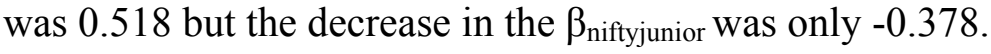

Table 3. Results of Bivariate regression

Panel A- Changes in co-movement measured by daily beta before and after addition of stocks to Nifty index and before and after exclusion from the Niftyjunior index

\begin{tabular}{|c|c|c|c|c|c|c|}
\hline & $\begin{array}{c}\text { No. of } \\
\text { Period }\end{array}$ & $\begin{array}{c}\text { Average } \\
\text { additions beta } \\
\text { before } \\
\text { inclusion }\end{array}$ & $\begin{array}{c}\text { Average } \\
\text { Nifty beta } \\
\text { after } \\
\text { inclusion }\end{array}$ & & $\begin{array}{c}\text { Increase in } \\
\text { beta }\end{array}$ & $\begin{array}{c}\text { \% of stocks } \\
\text { with beta } \\
\text { increase }\end{array}$ \\
\hline $1999-2010$ & 41 & 0.284 & 0.832 & $\beta_{\mathrm{c}}$ & $\mathbf{0 . 5 3 2}$ & $81 \%$ \\
\hline & & & & t-stat & $5.183 * * *$ & \\
\hline $1999-2006$ & 26 & 0.269 & 0.833 & $\beta_{\mathrm{c}}$ & $\mathbf{0 . 5 3 9}$ & $77 \%$ \\
\hline & & & & t-stat & $3.787 * * *$ & \\
\hline $2007-2010$ & 15 & 0.310 & 0.819 & $\beta_{\mathrm{c}}$ & $\mathbf{0 . 5 1 8}$ & $87 \%$ \\
\hline & & & & t-stat & $3.660 * * *$ & \\
\hline
\end{tabular}

Panel A- Changes in co-movement measured by daily beta before and after exclusion from the Niftyjunior index(ie addition to Nifty index)

\begin{tabular}{|c|c|c|c|c|c|c|}
\hline Period & $\begin{array}{c}\text { No. of } \\
\text { additions }\end{array}$ & $\begin{array}{c}\text { Average } \\
\text { NiftyJr } \\
\text { beta before } \\
\text { deletion }\end{array}$ & $\begin{array}{l}\text { Average } \\
\text { NiftyJr } \\
\text { beta after } \\
\text { deletion }\end{array}$ & & $\begin{array}{c}\text { Decrease } \\
\text { in beta }\end{array}$ & $\begin{array}{c}\% \text { of stocks } \\
\text { with beta } \\
\text { decrease }\end{array}$ \\
\hline \multirow[t]{2}{*}{$1999-2010$} & 41 & 0.832 & 0.390 & $\beta_{\mathrm{c}}$ & -0.442 & $75 \%$ \\
\hline & & & & t-stat & $-4.708 * * *$ & \\
\hline \multirow[t]{2}{*}{ 1999-2006 } & 26 & 0.833 & 0.355 & $\beta_{\mathrm{c}}$ & -0.479 & $73 \%$ \\
\hline & & & & t-stat & $-4.055 * * *$ & \\
\hline \multirow[t]{2}{*}{$2007-2010$} & 15 & 0.829 & 0.451 & $\beta_{\mathrm{c}}$ & -0.378 & $80 \%$ \\
\hline & & & & t-stat & $-2.395 * *$ & \\
\hline
\end{tabular}

The sample of addition to Nifty index for the period 1999-2010 consists of 41 added stocks which are not involved in mergers/demerger and related events and have sufficient daily data. In this bivariate regression, for each added stock the betas are estimated for both the pre-change and post-change period for both the Nifty index and the Niftyjunior index as top stocks from the Niftyjunior index are added to the Benchmark Nifty index based on predetermined criteria. Pre-change betas and post-change betas are calculated using daily data for the period AD-130 to AD-10 and period ED+10 to ED+130 respectively(120 trading days) using daily log returns in bivariate market model. The statistical significance is tested cross sectionally using one-tailed t-test. $* * *, * *, *$ denotes statistical significance at $1 \%, 5 \%$ and $10 \%$ level respectively. 


\subsection{The non-synchronous trading hypothesis}

According to Scholes and Williams (1977), index trading strategies around Nifty index additions increases the trading frequency of the included stocks which enables those stocks to incorporate market wide information immediately compared to non-Nifty stocks which impound information with a lag. The study shows that non-synchronous trading also biases the estimated stock betas. According to their model, betas of added stocks will increase as their trading volume moves closer to market average and not in other cases. The non synchronous trading hypothesis therefore implies that beta of added stocks will increase only if the post addition trading volume is greater than pre addition volume. Heavy trading helps in the incorporation of market wide information efficiently in the Nifty index stocks compared to non-nifty stocks. This is similar to the Barberis et al (2004) information diffusion view ${ }^{15}$. The implication is that the added stocks which are less frequently traded pre addition should witness beta increase due to the increased trading activity of institutional investors in the added stocks. Price pressure hypothesis predicts betas of added stocks will increase in all the cases.

The methodology developed by Vijh(1994) and later modified by Coakley and Kougalis (2004) is used in this study. The sample of 41 added stocks are grouped into two groups based on their trading volume. The first group consists of added stocks whose post-addition volume decreased and the second group consists of added stocks whose post-addition volume increased. All the added stocks are grouped in either one of the groups based on the above criteria. If the increased co-movement, as measured by increased beta subsequent to Nifty index additions, is due to non-synchronous trading, then only the second group should evidence beta increase. If the increased co-movement as measured by increased beta subsequent to Nifty index additions is due to the price pressure caused by index trading strategies, both groups should evidence beta increase.

The results are tabulated in table 4. While Panel A reports the beta change for stocks for which trading volume decreased post addition, Panel B reports the beta change for stocks for which trading volume increased post addition. As an additional measure, Panel $\mathrm{C}$ reports beta change ordered based on quintile change using trading volume. According to the price pressure hypothesis, beta should increase post addition in both the groups and in all the quintiles. Whereas the non-synchronous trading hypothesis expects the beta increase only for second group (panel B).

The beta change for the stocks for which trading volume decreased post addition decreased by 0.011 (median: - 0.07) for the complete period as predicted by non-synchronous trading view and beta change for the stocks for which trading volume increased post addition is a increase of 0.267 (median: 0.272). The results for the both the sub-periods are similar to the full periods in both the panels. The results are corroborated by the median values and percentage of stocks with beta increase in both the panels. For the complete period, only $36 \%$

\footnotetext{
15 The information diffusion view contends that the large liquid stocks impound information efficiently compared to smaller less liquid stocks and consequently priced fairly most of the time. This implies that the Nifty index would lead the other secondary indices in the Indian stock market. Please see appendix I for the results supporting the information diffusion view in the Indian stock market.
} 
of added stocks report beta increase for Panel A stocks. Whereas the beta increase for the panel B stocks' is $73 \%$ of added stocks. In Panel C, where stocks are arranged into three quintiles based on average trading volume, the beta increase from the lowest to highest quintile is - 0.06 (median: - 0.107), 0.192 (median: 0.168) and 0.285 (median: 0.294) respectively. The above results are presented to suggest that the results are not due to outliers or stock selection. Further, nonparametric, two independent sample test compared the beta change between Panel A and Panel B stocks rejected the equality of mean at $1 \%$ level. The results support the non-synchronous trading hypothesis in the Indian stock market and are different from the results in the developed markets.

Table 4. Testing the price pressure against the non-synchronous trading hypothesis

\begin{tabular}{|c|c|c|c|c|c|c|c|}
\hline \multicolumn{8}{|c|}{$\begin{array}{c}\text { Panel - A Stocks for which trading volume decreased post inclusion: } \\
\text { Volume Ratio(VR) is less than one }\end{array}$} \\
\hline \multirow[t]{2}{*}{ PERIOD } & Sample & \multicolumn{2}{|c|}{ Increase in beta } & \multirow[t]{2}{*}{$\begin{array}{c}\text { Average } \\
\text { Volume } \\
\text { Ratio VR }\end{array}$} & \multirow[t]{2}{*}{$\begin{array}{c}\% \text { of stocks } \\
\text { with beta } \\
\text { increase }\end{array}$} & \multirow[t]{2}{*}{$\begin{array}{l}\text { Prediction } \\
\text { of price } \\
\text { pressure } \\
\text { hypothesis }\end{array}$} & \multirow[t]{2}{*}{$\begin{array}{c}\text { Prediction of } \\
\text { non-synchronous } \\
\text { trading } \\
\text { hypothesis }\end{array}$} \\
\hline & & Mean & Median & & & & \\
\hline $1999-2010$ & 19 & -0.011 & -0.070 & 0.53 & $36 \%$ & increase & decrease \\
\hline $1999-2006$ & 10 & -0.034 & -0.050 & 0.43 & $40 \%$ & increase & decrease \\
\hline $2007-2010$ & 9 & 0.014 & -0.070 & 0.65 & $33 \%$ & increase & decrease \\
\hline \multicolumn{8}{|c|}{ Panel - B } \\
\hline \multirow[t]{2}{*}{ PERIOD } & Sample & \multicolumn{2}{|c|}{ Increase in beta } & $\begin{array}{c}\text { Average } \\
\text { Volume } \\
\text { Ratio VR }\end{array}$ & $\begin{array}{c}\% \text { of stocks } \\
\text { with beta } \\
\text { increase }\end{array}$ & $\begin{array}{c}\text { Price } \\
\text { pressure } \\
\text { Prediction }\end{array}$ & $\begin{array}{l}\text { Non- sync } \\
\text { trading } \\
\text { Prediction }\end{array}$ \\
\hline & & Mean & Median & & & & \\
\hline $1999-2010$ & 22 & $0.267 *$ & 0.272 & 2.67 & $73 \%$ & increase & increase \\
\hline $1999-2006$ & 16 & $0.237^{*}$ & 0.236 & 2.69 & $66 \%$ & increase & increase \\
\hline $2007-2010$ & 6 & $0.346^{*}$ & 0.372 & 2.35 & $83 \%$ & increase & increase \\
\hline \multicolumn{8}{|c|}{ Panel - C Daily beta as a function of trading volume } \\
\hline $\begin{array}{c}\text { Quintile of } \\
\text { volume ratio }\end{array}$ & Sample & \multicolumn{2}{|c|}{ Increase in beta } & Average VR & $\begin{array}{c}\% \text { of stocks } \\
\text { with beta } \\
\text { increase }\end{array}$ & $\begin{array}{c}\text { Price } \\
\text { pressure } \\
\text { Prediction }\end{array}$ & $\begin{array}{l}\text { Non- sync } \\
\text { trading } \\
\text { Prediction }\end{array}$ \\
\hline \multirow[t]{2}{*}{$1999-2010$} & 41 & \multicolumn{2}{|c|}{0.140} & 1.64 & $57 \%$ & & \\
\hline & & Mean & Median & & & & \\
\hline Lowest & 14 & -0.06 & -0.107 & 0.44 & $30 \%$ & increase & decrease \\
\hline Middle & 14 & $0.192 *$ & 0.168 & 1.05 & $77 \%$ & increase & increase \\
\hline Highest & 13 & $0.285^{*}$ & 0.294 & 3.39 & $64 \%$ & increase & increase \\
\hline
\end{tabular}


The sample of addition to Nifty index for the period 1999-2010 consists of 41 added stocks which are not involved in mergers and related events and have sufficient daily data. For each added stock the betas are estimated for both the pre-change and post-change period. Pre-change betas and post-change betas are calculated using daily data for the period AD-130 to AD-10 and period ED+10 to ED+130 respectively(120 trading days) using daily log returns in univariate and bivariate market model. The volume effect is studied in the spirit of Harris and Gurel(1986) where

Volume Ratio VR $=(\mathrm{Vit} / \mathrm{Vmt}) \div(\mathrm{Vi} / \mathrm{Vm})$

Where Vit and Vmt are the trading volumes of security I and the total NSE respectively, and Vi and Vm are the average trading volumes of the security I and total NSE for the period AD-70 through AD-10. The calculated daily VR is used to calculate the 'VR' for the period ED+10 to ED+70. The volume ratio should have a value of 'one' under null hypothesis. If for a stock $\mathrm{VR}>1$ then post inclusion volume is more than the pre inclusion volume and vice versa. The quintile ranking is based on VR. The statistical significance is tested cross sectionally using one-tailed t-test. * denotes statistical significance at $5 \%$ level.

Further, Coakley and Kougalis (2004) considered the bivariate changes and suggested that non-synchronous trading could explain the results if the ratio of absolute increase in Nifty beta $\beta_{\mathrm{i}, \text { nifty }}$ to absolute decrease in Nifty Junior beta $\beta_{\mathrm{i}, \text { niftyjunior }}$ is larger for the second group in Panel B compared to Panel A in Table 3. While the ratio for the first group (Panel A) is 0.872, the ratio for the second group (Panel B) is more than double at 1.672 (almost 100\% increase). The above result seems to confirm that the non-synchronous trading view as the major explanation for co-movement subsequent to Nifty index changes.

\subsection{Non-synchronous trading and Auto-correlations}

According to Greenwood and Sosner (2002), pricing effects due to index trading strategies should eventually end and as a result added stocks should co-move strongly immediately after addition but later revert to reflect fundamentals. He argues that the resulting effect would be negative auto-correlations for the added stocks and vice versa for deleted stocks. Coakley et al(2008) argues that if non-synchronous trading effects dominate, then the autocorrelations of the added stocks should become more positive. The variance ratio test is used to test whether the auto correlation becomes more negative for the added stocks and less negative for the deleted stocks.

Lo A.W. and A.C. MacKinlay(1988) enunciated the powerful Variance Ratio test which is based on variance of returns and have good size and power properties over other tests. The authors have reviewed the Overlapping Variance Ratio tests and have concluded that for moderate to large samples and proper choice of holding period "q", the variance ratio test is better than many other similar tests. The test is based on the fact that the variance of the increment of a random walk is linear in the sampling interval. This statistic compares one period return with longer period returns. The variance ratio less than / more than ' 1 ' represents negative / positive auto correlation respectively. 
Table 5. Autocorrelation between a stocks' current return to its past return for stocks added / deleted to/from Nifty index for the 1999-2010 period using Variance ratio.

\begin{tabular}{|c|c|c|c|c|c|c|}
\hline $\begin{array}{l}\text { ADDITION } \\
\mathrm{N}=\mathbf{4 0}\end{array}$ & \multicolumn{2}{|c|}{ Pre event } & \multicolumn{2}{|c|}{ Post event } & \multicolumn{2}{|c|}{ Difference } \\
\hline Mean Variance Ratio ${ }^{16}$ at & $q=2$ & $q=5$ & $q=2$ & $q=5$ & $q=2$ & $q=5$ \\
\hline Period - 1999-2010 & 1.041 & 1.027 & 1.048 & 1.048 & $0.63 \%$ & $2.02 \%$ \\
\hline Sub period - 1999-2006 & 1.037 & 1.029 & 1.067 & 1.065 & $2.33 \%$ & $3.45 \%$ \\
\hline Sub period - 2007-2010 & 1.049 & 1.024 & 1.026 & 1.020 & $-2.19 \%$ & $-0.38 \%$ \\
\hline $\begin{array}{l}\text { DELETION } \\
\mathbf{N}=30\end{array}$ & \multicolumn{2}{|c|}{ Pre event } & \multicolumn{2}{|c|}{ Post event } & \multicolumn{2}{|c|}{ Difference } \\
\hline Mean Variance Ratio at & $q=2$ & $q=5$ & $q=2$ & $q=5$ & $q=2$ & $q=5$ \\
\hline Period - 1999-2010 & 1.009 & 1.013 & 1.046 & 1.068 & $3.72 \%$ & $5.45 \%$ \\
\hline Sub period - 1999-2006 & 1.008 & 0.996 & 1.052 & 1.071 & $4.42 \%$ & $7.56 \%$ \\
\hline Sub period $-2007-2010$ & 1.011 & 1.041 & 1.036 & 1.062 & $2.50 \%$ & $1.98 \%$ \\
\hline $\begin{array}{l}\text { The sample of addition to } \\
\text { stocks and } 30 \text { deleted stoc } \\
\text { have sufficient daily data. } \\
\text { current period stock retur } \\
\text { pre-change and post-chan } \\
\text { AD-130 to AD-10 and p } \\
\text { variance ratio. The variar } \\
1 \text { implies positive aut } \\
\text { autocorrelation. }\end{array}$ & $\begin{array}{l}\text { and each } \\
\text { period } \\
\text { od ED } \\
\text { ratio o } \\
\text { rrelati }\end{array}$ & $\begin{array}{l}\text { ed/del } \\
\text { perio } \\
\text { ng da } \\
\text { to ED } \\
\text { indic } \\
\text { and }\end{array}$ & $\begin{array}{l}\text { stock } \\
\text { ock ret } \\
\text { lata(dai } \\
0 \text { respe } \\
\text { zero at } \\
\text { ance }\end{array}$ & $\begin{array}{l}\text { autoco } \\
\text { log ret } \\
\text { vely }(12 \\
\text { correla } \\
\text { io }<\end{array}$ & $\begin{array}{l}\text { nsists o } \\
\text { related } \\
\text { elation b } \\
\text { mated fo } \\
\text { ns) for } \\
\text { trading c } \\
\text { on. Varia } \\
\text { implies }\end{array}$ & $\begin{array}{l}40 \text { added } \\
\text { vents and } \\
\text { ween the } \\
\text { both the } \\
\text { ne period } \\
\text { ys) using } \\
\text { ce ratio }> \\
\text { negative }\end{array}$ \\
\hline
\end{tabular}

Table 5 reports the variance ratio statistic calculated for each added/deleted stock for holding periods $\mathrm{q}=2,5$. Both the pre-change and post-change periods use 120 trading days each as the variance ratio is a powerful test in moderate and large samples. The results for the included stocks show an increase in mean auto correlation contrary to the predictions of the price pressure/index trading strategies. The first order auto-correlation at holding period $\mathrm{q}=2$ and week long q=5 increase by $0.63 \%$ and $2.02 \%$ respectively for the complete period. For the first sub period the results are similar to the complete period but for the second recent sub-period there is marginal reduction in the autocorrelations.

16 The median values suggest even stronger increases in the complete period and both the sub periods for the added / deleted stocks. ex. For added stocks, for the second sub period, auto correlation increases at all lags. VR was not calculated for one stock as it had only prechange period of only 60 days 
The results for the deleted stocks show that the autocorrelation increases between pre and post event for complete period and both the sub periods. The first order auto correlation increases by $3.72 \%$ and weeklong auto-correlation increases by $5.45 \%$ for the complete period. Though the changes between the pre change and post change auto correlations are not statistically significant ${ }^{17}$ for both the additions and deletion for all the holding periods ${ }^{18}$, the results for the additions do not support the price pressure/index trading explanations as the explanation for the co-movement subsequent to index additions. This result seen along with the other results for slow information diffusion and non-synchronous trading appears to suggest that the information related explanations rather than the trading based explanations explain the Nifty index changes after addition to or deletion from the nifty index during the period 1999-2010.

\section{Conclusion}

This study set out to empirically analyse the co-movement between the added/deleted stocks and the Nifty index subsequent to Nifty index changes in order to discriminate between the two competing explanations: The fundamental based approach which attributes return co-movement to correlation in news about fundamentals and the friction based or the index trading strategies based approach.

The results for the univariate regressions for Nifty index additions evidence significant increase in co-movement post addition. However, contrary to the results in the developed markets the Nifty index deletions too experience increase in co-movement (though not statistically significant). The bivariate regressions for Nifty index additions evidence significant increase in co-movement post addition. But both the univariate and bivariate regressions do not evidence significant increase in co-movement in the recent second sub period compared to the first sub period. The above results along with the tests conducted using the methodologies of Vijh(1994), Barberis et al(2002) and Greenwood and Sosner (2002), in contrast to the developed markets, suggest that the information related views explain co-movement subsequent to Nifty index changes better than other competing explanations.

An interesting finding is that the stock pricing become less efficient when the non-Nifty stocks become Nifty index stocks based on the auto correlation results. This has implications for the efficient market theory. Due to increased trading and visibility subsequent to index addition, pricing of added stocks should become more efficient after addition to the benchmark index. Further, the lack of symmetric response to additions and deletions seem to support the Chen et al (2004) explanation of 'investor awareness' as an explanation index changes in the Indian stock market. Overall, the results suggest that information related explanations explain Nifty index changes better than other competing explanations.

\section{Acknowledgement}

I thank Dr. Victor Louis Anthuvan, Professor of Finance, Chairperson PhD, Loyola Institute of Business Administration, Chennai-600034, for his guidance and support throughout the study.

\footnotetext{
17 using both parametric (two sample t-test) and non-parametric tests (two paired sample comparison test)..

18 The results for $\mathrm{q}=3$ and $\mathrm{q}=4$ are similar to the reported results for both additions and deletions.
} 
I also thank Prof. Lodewijk Berlage, Professor Emeritus, Katholike University, Leuven, Belgium, for his valuable suggestions.

\section{References}

Amihud, Y., \& Mendelson, H. (1986). Asset pricing and the bid-ask spread. Journal of Financial Economics, 17, 223-249. http://dx.doi.org/10.1016/0304-405X(86)90065-6

Barberis, N., Shliefer, A. Wurgler, J. (2002). Comovement. NBER working paper No.8884.

Barberis, N., Shliefer, A., \& Wurgler, J. (2005). Comovement. Journal of Financial Economics, 75, 283-317. http://dx.doi.org/10.1016/j.jfineco.2004.04.003

Baur, D., (2003). What is comovement?. European Commisssion, Joint Research Centre, ISPRA(VA), Italy.

Bekaert, G., \& Harvey, C.R. (2003). Emerging market finance. Journal of Empirical Finance, 10, 3-55. http://dx.doi.org/10.1016/S0927-5398(02)00054-3

Brown, S.J., \& Warner, J.B. (1985). Using daily stock returns: The case of event studies. Journal of Financial Economics, $14(1), \quad 31$. http://dx.doi.org/10.1016/0304-405X(85)90042-X

Chakrabarti, R., Huang, W., \& Jayaraman, N., Lee, J. (2005). Price and volume effects of changes in the MSCI indices - Nature and Causes. Journal of Banking and Finance, 29, pp. 1237-1264. http://dx.doi.org/10.1016/j.jbankfin.2004.04.002

Chen, H., Noronha, \& G. Singhal, V. (2004). The price response to S\&P 500 additions and deletions: Evidence of asymmetry and a new explanation. Journal of Finance, 59(4), pp. 1901-1929. http://dx.doi.org/10.1111/j.1540-6261.2004.00683.x

Coakley, J., Kougoulis, \& P. Nankervis, J.C. (2008). The MSCI - Canada index rebalancing and excess co-movement. Applied Financial Economics, 18, pp.1277-1287. http://dx.doi.org/10.1080/09603100701537722

Coakley, J., Kougoulis, P., \& Nankervis, J.C. (2004). Co-movement and FTSE 100 changes. discussion paper, University of Essex.

Greenwood, M.R., \& Sosner N. (2002). Where do beats come from? Working paper, Harvard University.

Greenwood, M.R., \& Sosner N. (2003). Trade and Co-movement of stock returns, Evidence from Japan. Working paper, Harvard University.

Greenwood, M.R., Sosner N. (2007). Trading patterns and excess co-movement of stock returns. Financial Analyst Journal, Vol 63, No.5. http://dx.doi.org/10.2469/faj.v63.n5.4841

Harris, L., \& Gurel, E. (1986). Price and volume effects associated with changes in the S\&P 500 list, New evidence for the existence of price pressures. Journal of Finance, 41, 815-829. http://dx.doi.org/10.2307/2328230 
Hacibedel, B. (2008). Index changes in emerging markets. Swedish Institute of financial research working paper, saltmatagatan, 19A, SE-113, 59, Stockholm, Sweden.

Kasch, M., \& Sarkar, A. (2009). Are Comovement ec=xcessive? Working Paper (March), University of Bonn; Available at SSRN: http://ssrn.com/abstract=1364539.

Lo, A. W., \& MacKinlay, A. C. (1988). Stock Market Prices Do Not Follow Random Walks: Evidence from a Simple Specification Test. Review of Financial Studies, Vol. 1, No. 1 (Spring), pp. 41-66. http://dx.doi.org/10.1093/rfs/1.1.41

Lo, A. W., \& MacKinlay, A. C. (1989). The Size and Power of the Variance Ratio Test in Finite Samples: A Monte Carlo Investigation. Journal of Econometrics, Vol. 40, pp.203-238. http://dx.doi.org/10.1016/0304-4076(89)90083-3

Lynch, A., \& Mendenhall, R. (1997). New evidence on stock price effects associated with changes in the S\&P 500. Journal of Business, 70, 351-384. http://dx.doi.org/10.1086/209722

Mitchel, M., Pulvino, T. \& Stafford, E. (2004). Price Pressure around Mergers. Journal of Finance, 59, 1, pp. 31-63. http://dx.doi.org/10.1111/j.1540-6261.2004.00626.x

National Stock Exchange website, nse-india.com.

Parthasarthy, S. (2010). Price and Volume Effects Associated with Index Additions: Evidence from the Indian Stock Market. Asian Journal of Finance \& Accounting, Vol 2. No.2, pp.55-80.

Scholes, M.S., \& Williams, J.T. (1977), Estimating betas from non-synchronous data. Journal of Financial Economic, 5, 309-327. http://dx.doi.org/10.1016/0304-405X(77)90041-1

Shleifer, A. (1986). Do demand curve for stocks slope down? Journal of Finance, 41, 579-590. http://dx.doi.org/10.2307/2328486

Vijh, A.M. (1994). S\&P 500 trading strategies and stock betas. Review of Financial Studies, 7, 215-251. http://dx.doi.org/10.1093/rfs/7.1.215

Wurgler, J., \& Zhuravskaya, E. (2002). Does arbitrage flatten demand curve for stocks? Journal of Business, 75, 583-608. http://dx.doi.org/10.1086/341636

Yafeh, Y., \& Claessens, S. (2009). Additions to market indices and the co-movement of stock returns around the world. www.cepr.org/ pubs/dps/DP7052.asp., Centre for Economic Policy Research.

\section{Appendix}

The information diffusion view contends that the large liquid stocks impound information efficiently compared to smaller less liquid stocks and consequently priced fairly most of the time. This implies that the Nifty index would lead the other secondary indices in the Indian stock market. Barberis et al (2004) differentiates between the category - habitat theories with that of slow information diffusion view (fundamental view) for co-movement subsequent to index changes. Coakley and Kougalis(2004) studying FTSE 100 additions in the London 


\section{Macrothink}

stock market evidence that the bench mark FTSE 100 index leads other secondary indices up to five lags.

Granger causality test is used to test whether Nifty index returns causes or leads the non-Nifty returns or vice versa in the Indian stock market. According to Granger causality, if a series $\mathrm{X}$ granger causes or leads a series $\mathrm{Y}$, then past values of $\mathrm{X}$ should contain information to predict $\mathrm{Y}$ above and beyond the information contained in the past values of $\mathrm{Y}$ alone.

Granger causality is normally tested in the context of linear regression models. Granger causality measures precedence and information content but does not indicate causality in the normal sense of the term. Consider the following bivariate linear auto regressive model

$$
\begin{array}{r}
\text { Rnifty }_{t}=\alpha+\sum_{i=1}^{p} \beta_{i} \text { Rnifty }_{t-i}+\sum_{i=1}^{p} \gamma_{i} \text { Rniftyj }_{t-i}+u_{v, t} \\
\text { Rniftyj }_{t}=\alpha+\sum_{i=1}^{p} \beta_{i} \text { Rniftyjr }_{t-i}+\sum_{i=1}^{p} \gamma_{i} \text { Rnifty }_{t-i}+u_{r, t}
\end{array}
$$

Where, 'p' is maximum number of lagged observations included in the model. Rnifty, Rniftyjr represents Nifty return and Niftyjunior return respectively. This study uses 3 lags as determined by Akaike Information Criterion(AIC) and Schwarz criterion. In the equation (6), If $\gamma_{i}$ coefficients are statistically significant, then including lagged values of both nifty returns series and Niftyjunior returns series gives a better forecast of Niftyjunior returns. In this study, bivariate regression is run for all possible combinations in the group. The reported F-statistic is the Wald statistic test is used to test for joint hypothesis,

$$
\gamma_{1}=\gamma_{2}=\ldots . .=\gamma_{i}=0
$$

for each equation. The null hypothesis is that the Niftyjunior returns does not granger cause or leads Nifty returns in eq(5) and Nifty returns does not granger cause or leads Nifty Junior returns(eq 6). 
Table 5. Tests for information diffusion among the Nifty, Niftyjunior and CNX 500 indices using Granger causality tests.

\begin{tabular}{l|l|c|c|c|}
\hline \multicolumn{5}{|c|}{ Panel A - Null hypothesis: Nifty returns do not granger cause/lead Niftyjunior and CNX 500 } \\
returns.
\end{tabular}

Panel B - Null hypothesis: Niftyjunior and CNX 500 returns do not granger cause/lead Nifty returns.

\begin{tabular}{|l|l|c|c|c|}
\hline & & lag 1 & lag 2 & lag 3 \\
\hline Nifty junior & F-stat & 0.22 & 0.22 & 0.56 \\
\hline & p-value & 0.639 & 0.639 & 0.641 \\
\hline & & & & \\
\hline CNX 500 & F-stat & 2.47 & 2.13 & 1.47 \\
\hline & p-value & 0.116 & 0.119 & 0.220 \\
\hline
\end{tabular}

The Nifty, Niftyjunior and the CNX 500 daily return series is calculated for the period between 01-01-2000 to 31-03-2010. The granger causality as to whether the Nifty returns leads/granger causes both Niftyjunior and CNX 500 is tested. *, **, *** represents singnificance at $10 \%, 5 \%, 1 \%$ level.

The tests are conducted using three indices, namely Nifty index, Nifty Junior index and the broad based CNX 500 index. The Nifty index constitutes the top 50 large, liquid stocks. The Nifty junior index ${ }^{19}$ constitutes the next 50 stocks based on market capitalization (may be regarded as a Midcap index). The CNX 500 index consists of top 500 stocks in the Indian stock market and includes both Nifty stocks and Nifty junior stocks. If slow information diffusion plays a major role in the co-movement subsequent to index additions in the Indian stock market then a) Nifty returns must granger cause or lead both the Nifty Junior and CNX 500 returns b) CNX 500 returns must granger cause or lead Nifty Junior returns. If that is not the case, then category/habitat views explain the co-movement subsequent to index additions. The data between 01-01-2000 and 31-03-2010 is used as data for CNX 500 is available only from the second half of the year 1999.

Table V presents the results of the F-test along with the corresponding significance level. The results in Panel A show that the null hypothesis Nifty returns do not granger cause/lead Niftyjunior is rejected for lags 1 and 3 at 5\% and 10\% significance level respectively. Similarly the null hypothesis that Nifty returns do not granger cause/lead CNX 500 is rejected for lags 1 and 2 at 10\% significance level. However Panel B results show that the hypothesis Nifty Junior

\footnotetext{
19 The S\&P CNX Nifty and the CNX Nifty Junior make up the 100 most liquid stocks in India with Nifty constituting the top 50 stocks and Nifty junior the next 50 stocks. The maintenance of the S\&P CNX Nifty and the CNX Nifty Junior are synchronized so that the two indices will always be disjoint sets; i.e. a stock will never appear in both indices at the same time.
} 
and CNX 500 returns do not granger cause/lead Nifty returns is not rejected at any level of significance.

The results suggest that Nifty index returns lead $^{20}$ both Nifty junior and CNX 500 indices between one to three days. The results suggest that the market wide information gets reflected in the Nifty index stocks immediately while it gets reflected in the Nifty junior index stocks after a lag of three days as would be expected from the slow diffusion view. AIC and Schwarz criterion restricted the lags to 3, Nifty Junior index lag Nifty index up to at least 8 lags. 